\title{
Molecular Characterization of Myiasis-Causing Moth Flies (Diptera: Psychodidae)
}

Myiasis Nedeni Güve Sineklerinin (Diptera: Psychodidae) Moleküler Karakterizasyonu

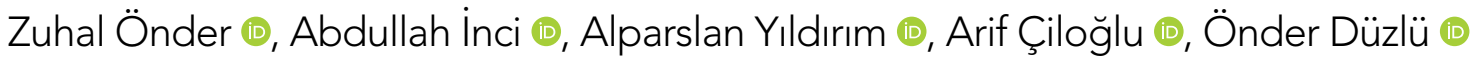 \\ Department of Parasitology, Erciyes University School of Medicine, Kayseri, Turkey
}

Cite this article as: Önder Z, İnci A, Yıldırım A, Çiloğlu A, Düzlü Ö. Molecular Characterization of Myiasis-Causing Moth Flies (Diptera: Psychodidae). Turkiye Parazitol Derg 2018; 42(3): 223-8.

\section{ABSTRACT}

Objective: The aim of this study is to examine the molecular characterization of moth flies (Diptera: Psychodidae) based on their mitochondrial DNA sequences and determine the vectorial potential and damage caused by moth flies in future researches.

Methods: A total of 240 adult moth flies were collected from toilet, bathroom, and basement walls of houses from different locations of the Kayseri region between May 2016 and April 2017. The polymerase chain reaction (PCR) analyses were performed using primer pairs, specificaly targeting the mitochondrial cytochrome oxidase c subunit I (mt-COI) gene of adult flies.

Results: In total, five isolates were gel purified and sequenced for molecular characterization and phylogenetic analyses. Two species, namely Telmatoscopus albipunctatus (ERU-Telmatos3 and ERU-Telmatos6) and Psychodidae sp. (ERU-Psycho1,4,5), were successfully identified with the sequence alignment of isolates. According to the phylogenetic analysis, it was determined that the ERU-Telmatos 3 and ERU-Telmatos6 isolates are clustered in the haplogroup A, while the ERU-Psycho1,4,5 isolate was clustered within the haplogroup B. The ERU-Psycho1 isolate was characterized as a new haplotype within the haplogroup B.

Conclusion: This study represents the first molecular characterization and phylogenetic status of moth flies in Turkey. The obtained findings should be the first step in the future investigation based on detecting the transmission of bacterial pathogens by moth flies.

Keywords: Moth fly, myiasis, molecular characterization, phylogenetic analysis

Received: 16.03.2018

Accepted: 03.05 .2018

\section{Öz}

Amaç: Bu çalışma, mitokondrial DNA sekansı temelinde güve sineklerinin (Diptera: Psychodidae) moleküler karakterizasyonunu, gelecek araştırmalarda bu sineklerin neden olduğu zararları ve vektörlük potansiyellerini belirlemek amacıyla yapılmışıı.

Yöntemler: Mayıs 2016-Nisan 2017 yılları arasında Kayseri'nin çeşitli bölgelerinde konutların banyo, tuvalet ve bodrum duvarlarından toplam 240 ergin güve sineği toplanmıştr. Ergin sineklerin mitokondrial sitokrom oksidaz I (COI) gen bölgesini amplifiye eden spesifik primer çiftleri ile polimeraz zincir reaksiyonu (PCR) analizleri yapılmıştır.

Bulgular: Toplam 5 izolat moleküler karakterizasyon ve filogenetik analizler için jel pürifiye edilip sekanslanmıştır. İzolatların sekans analizleri ile Telmatoscopus albipunctatus (ERU-Telmatos3 ve ERU-Telmatos6) ve Psychodidae sp. (ERU- Psycho1,4,5) türleri identifiye edilmiştir. Filogenetik analizlere göre ERU-Telmatos3 ve ERU-Telmatos6 izolatları haplogroup A içinde, ERU-Psycho1,4,5 izolatları ise haplogroup B içinde kümelenmiştir. Aynı zamanda ERU-Psycho1 izolatı haplogroup B'de yeni bir haplotip olarak karakterize edilmiştir.

Sonuç: Bu çalışma, Türkiye'de güve sineklerinin moleküler karakterizasyonu ve filogenetik durumu üzerine ilk moleküler verileri sağlamıştır. Çalışma ile elde edilen sonuçlar, myiasis nedeni güve sineklerinin bakteriyel patojenlerin taşınması ve mekanik vektörlük potansiyellerinin belirlenmesi üzerine gelecek araştırmaların ilk basamağı olması bakımından oldukça orijinaldir.

Anahtar Kelimeler: Güve sineği, myiasis, moleküler karakterizasyon, filogenetik analiz

Geliş Tarihi: 16.03.2018

Kabul Tarihi: 03.05.2018

\section{INTRODUCTION}

The Psychodidae family has a cosmopolitan distribution, with approximately 3000 described species in six subfamilies (Horaiellinae, Sycoracinae, Trichomyiinae, Bruchomyiinae, Phlebotominae, and Psychodinae) $(1,2)$. The subfamily Psy- chodinae is commonly known as the drain, moth, or filter fly because these are commonly found on the sites of buildings, such as sewers, cesspools, septic tank, sewage treatment plants, and other dark and moist places (3). The females of moth flies are not blood feeding, and they feed on flower

Address for Correspondence / Yazışma Adresi: Zuhal Önder E.mail: zuhalbiskin@erciyes.edu.tr DOI: $10.5152 /$ tpd.2018.5943 
nectar, sewage, and other moisture sources. Their larval stages are coprophagous and saprophagous, and during these stages, they feed on a gelatinous film of decaying organic matter and vertebrate faeces (4-7).

Moth flies [Psychoda and Telmastoscopus (formerly Clogmia)] of the Psychodinae subfamily are of public health and veterinary consideration (8-10). Both genera are commonly found on basement walls, in homes, and in public places such as restrooms and the bathrooms in sports centeres, hospitals, and hotels (11). When the hairs of these flies are inhaled, people cannot breathe or function comfortably, and this may even trigger respiratory problems such as allergic rhinitis and asthma in humans (7). In addition, adult moth flies can be mechanical vectors of several bacterial pathogens associated with nosocomial infections. The moth fly larvae may cause accidental myiasis (e.g, urinary, intestinal, and nasal myiasis) $(4,10,12)$.

Correct species identification of the moth fly is highly important for pest control practices (13). According to external morphological characters, traditional morphological identification of the Psychodinae species is difficult (14).

At present, several DNA-based analyses have been developed for the specific identification and characterization of insect species. The mitochondrial DNA sequences have been successfully used for the identification of species in many different insect groups $(15,16)$. Two of the mitochondrial genes, cytochrome oxidase subunit I and II (COI and COII), are most reliable and popular molecular markers. Cytochrome c oxidase subunit I (COI) has highly conserved sequences and variable regions within vertebrates and insects (15-17). An understanding of evolutionary relationships among different subfamilies and species of the psychodid flies, especially in the moth flies, are of epidemiological importance, because the phylogenetic relationship helps to predict the mechanical transmission of bacterial pathogens such as Acinetobacter baumannii, Aeromonas hydrophila, Alcaligenes faecalis, Bacillus cereus, Escherichia coli, Klebsiella pneumoniae ssp. pneumoniae, Pseudomonas aeruginosa, P. fluorescens, and Stenotrophomonas maltophili in houses, hospitals (bathrooms, patient room toilets, and hospitals kitchens), and public toilets and bathrooms $(18,19)$. Therefore, the aim of this study was to determine the molecular characterization and phylogenetic status of the moth flies in Turkey.

\section{METHODS}

\section{Collection of Samples and Genomic DNA Isolation}

The fly specimens were collected from toilet, bathroom, and basement walls of houses from different locations of the Kayseri region between May 2016 and April 2017 using suitable nets. The captured flies were placed in $1.5 \mathrm{~mL}$ eppendorf tubes containing the $70 \%$ ethyl alcohol solution, and they were transported to the laboratory.

The whole body of each sample was crushed in a $1.5 \mathrm{ml}$ microcentrifuge tube with liquid nitrogen in a pre-cooled mortar. The total DNA was extracted individually from each crushed fly using the GeneJET Genomic DNA Purification Kit (Thermo Fisher
Scientific, USA) according to the manufacturer's instructions. The extracted genomic DNA samples were stored at $-20^{\circ} \mathrm{C}$ until the PCR analyses.

\section{PCR Amplification}

Extracted DNA from each sample was used to amplify a 709 bp fragment of the mitochondrial $\mathrm{CO}$ gene barcoding region using the LCO-1490 forward (5'-GGTCAACAAATCATAAAGATATTGG-3') and HCO-2198 reverse (5'-TAAACTTCAGGGTGACCAAAAAATCA-3') primers (20). The concentration and purity of extracted DNA was measured by a Qubit 3.0 fluorometer (Life Technologies).

The PCR was performed in a final reaction volume of $25 \mu \mathrm{L}$, containing $0.4 \mu \mathrm{M}$ of each primer, $0.2 \mathrm{mM}$ of each dNTP (Fermentas, Vilnius, Lithuania), $50 \mathrm{mM} \mathrm{KCl}, 10 \mathrm{Mm}$ Tris- $\mathrm{HCl}$ (pH 9.0), $4 \mathrm{mM}$ $\mathrm{MgCl} 2,1 \cup$ Taq DNA polymerase (Thermo Fisher Scientific, Hudson, NH, USA), and 50 ng of template DNA. DNase-RNase-free water was used as negative control. The reaction was performed in a C1000 Touch ${ }^{\mathrm{TM}}$ thermal cycler (Bio-Rad, USA), and this comprised an initial denaturation step at $94^{\circ} \mathrm{C}$ for $3 \mathrm{~min}$, followed by 39 cycles of denaturation at $94^{\circ} \mathrm{C}$ for $20 \mathrm{sec}$, primer annealing at $50^{\circ} \mathrm{C}$ for $20 \mathrm{sec}$, and a primer extension at $72^{\circ} \mathrm{C}$ for $30 \mathrm{sec}$. The final extension at $72^{\circ} \mathrm{C}$ for 10 min was performed, and samples were held at $4^{\circ} \mathrm{C}(17)$. The PCR products were electrophoresed on a $1.5 \%$ agarose gel containing $10 \mu \mathrm{L} / \mathrm{mL}$ ethidium bromide in the Tris-acetate-EDTA (TAE) buffer at $135 \mathrm{~V}$ for $30 \mathrm{~min}$ and visualized using the CLP Gel Documentation System (UVP INC Upland, CA).

\section{Sequence Alignment and Phylogenetic and Genetic Distance Analyses}

The amplified PCR products were gel purified using the High Pure PCR product purification kit (Roche, Mannheim, Germany) following the manufacturer's instructions. In addition, purified DNA was bidirectionally sequenced (Macrogen, Korea) with the same primers used to PCR amplify a 709 bp region of the mitochondrial $\mathrm{COI}$ gene. The nucleotide chromatograms were aligned with the Geneious 9.1.3 software [www.geneious.com (21)]. The DNA polymorphism, the number of haplotypes, and nucleotide diversity were determined using DnaSP 5.10.01 (22). Calculations for the mean genetic diversities within and among the haplogroups were performed with the MEGA version 6 (23) by the Kimura two-parameter distance model $(24,25)$.

Phylogenetic analyses were performed by the Bayesian (BA) inference. The best-fit DNA-substitution model based on the Akaike information criterion algorithm was determined as the General Time Reversible (GTR) by using jModeltest v.0.1.1 (26, 27). The BA analyses were set up in the MrBayes version 3.2.6 (28) and PhyML (29), respectively, by using the plugins available with the Geneious 9.1.3 software (www.geneious.com, 21). The species of moth flies in the Genbank used for phylogenetic analysis are detailed in Table 1.

The Markov chain simulations in the BA search were run for 10 million generations, with sampling every 200 generations for the posterior probability calculations. The $25 \%$ of the parameter estimates was discarded as burn-in. 
Table 1. Species used from Genbank for sequence alignment

\begin{tabular}{|c|c|c|c|}
\hline Genbank Accession No & Species & Isolate & Origin \\
\hline HQ979025 & Psychodidae sp. & BOLD:AAF9305 & USA \\
\hline KY924868 & Telmatoscopus albipunctatus & ERU-Telmatos3 & Kayseri, Turkey \\
\hline KX054540 & Psychodidae sp. & Sc_05918 & French Polynesia \\
\hline HQ978770 & Diptera sp. & BOLD:AAE5173 & Canada \\
\hline KR992085 & Psychodidae gen. PschodididGC sp. & BOLD-2016 & Canada \\
\hline KR988152 & Psychodidae gen. PschodididGC sp. & BOLD-2016 & Canada \\
\hline KR990808 & Psychodidae gen. PschodididGC sp. 1 & BOLD-2016 & Canada \\
\hline KY924855 & Psychodidae sp. & ERU-Psycho4 & Kayseri, Turkey \\
\hline KR722204 & Psychodidae gen. PschodididGC sp. & BOLD-2016 & Canada \\
\hline KY924864 & Psychodidae sp. & ERU-Psycho1 & Kayseri, Turkey \\
\hline
\end{tabular}

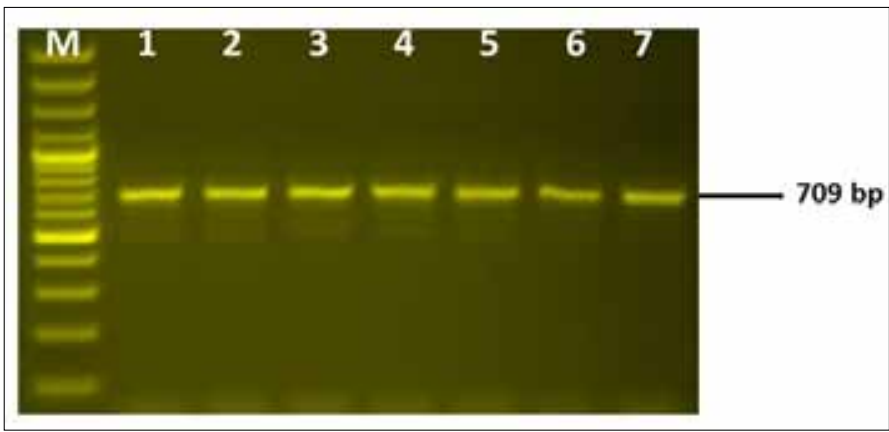

Figure 1. Amplification of the mitochondrial $\mathrm{COI}$ gene in moth flies. Lane M: 100 bp DNA ladder; lane 1-7: PCR products of the $\mathrm{COI}$ gene (the samples isolated from different parts of Kayseri)

\section{RESULTS}

\section{COI Sequences and Genetic Divergence}

A total of 240 adult flies were collected from 40 houses. A total of 50 genomic DNA isolates were amplified with the PCR and sequence analyses of the partial mt-COI gene region, and all the isolates displayed a successful amplification (Figure 1).

In total, five partial sequences (658 bp without primers) of moth flies specimens from the Kayseri region were obtained. According to sequence analyses of isolates, a total of two different moth flies (ERU-Telmatos3 and ERU-Telmatos6 isolates as Telmastocopus albipunctatus and ERU-Psycho4, ERU-Psycho5, and ERU-Psycho1 as Psychodidae sp.) were identified. A total of 31 polymorphic sites were distributed among the $\mathrm{COI}$ sequences of the isolates, leading to the detection of three different haplotypes (isolates ERU-Telmatos3 and ERU-Telmatos6 constituted the first, ERU-Psycho4 and ERU-Psycho5 constituted the second, and ERU-Psycho1 constituted the third haplotypes). The mean haplotype diversity among the sequences was $0.800 \pm 0.164$. The base composition was strongly AT biased for all species and similar to mitochondrial genes in insects (30); the mean GC content was 0.330 . All the sequences were submitted to the $\mathrm{NCBI}$-gene bank nucleotide database, and the accession number assigned was KY924864-68.

\section{Phylogenetic Analyses}

The BA tree is presented in Figure 2, with posterior probability (BA) and bootstrap support (ML) values. Two major haplogroups $(A$ and $B$ ) and one new haplotype were found in this study.

The isolates ERU-Telmatos3 and ERU-Telmatos6 were clustered with the isolates belonging to Telmatoscopus albipunctatus and Psychodidae sp., reported from India and the United States, , respectively, and they were placed under the haplogroup A1 with a high bootstrap support (100\%) and posterior probability (1.00) (Figure 2). The mean genetic diversity among the isolates in the $A 1$ haplogroup was $0.4 \pm 0.2 \%$. A mean genetic distance of $3.5 \pm 0.8 \%$ was determined between the haplogroup $A 1$ and the haplotype $A 2$, which clustered under the major group $A$. The isolates ERU-Psycho4 and ERU-Psycho5 showed a 100.0\% match with the isolates belonging to the Psychodidae sp. reported from Canada and constituted the B2 haplogroup with the contribution of ERU-Psycho1 isolate, which was characterized as a new haplotype (Figure 2). This phylogenetic resolution was also supported with a moderate bootstrap support (58\%) and posterior probability $(>0.56)$. The genetic difference between the ERU-Psycho1 isolate and other isolates under the B2 haplogroup was determined as $0.2 \pm 0.2 \%$. The B1 haplogroup included the isolates of Diptera sp. and Psychodidae sp. reported from the United States and Canada, and it showed mean genetic distances of $0.5 \pm 0.2 \%$ to the isolates of the B2 haplogroup. The mean genetic distances between the group $A$ and group B were designated as $5.6 \pm 1.0 \%$. 


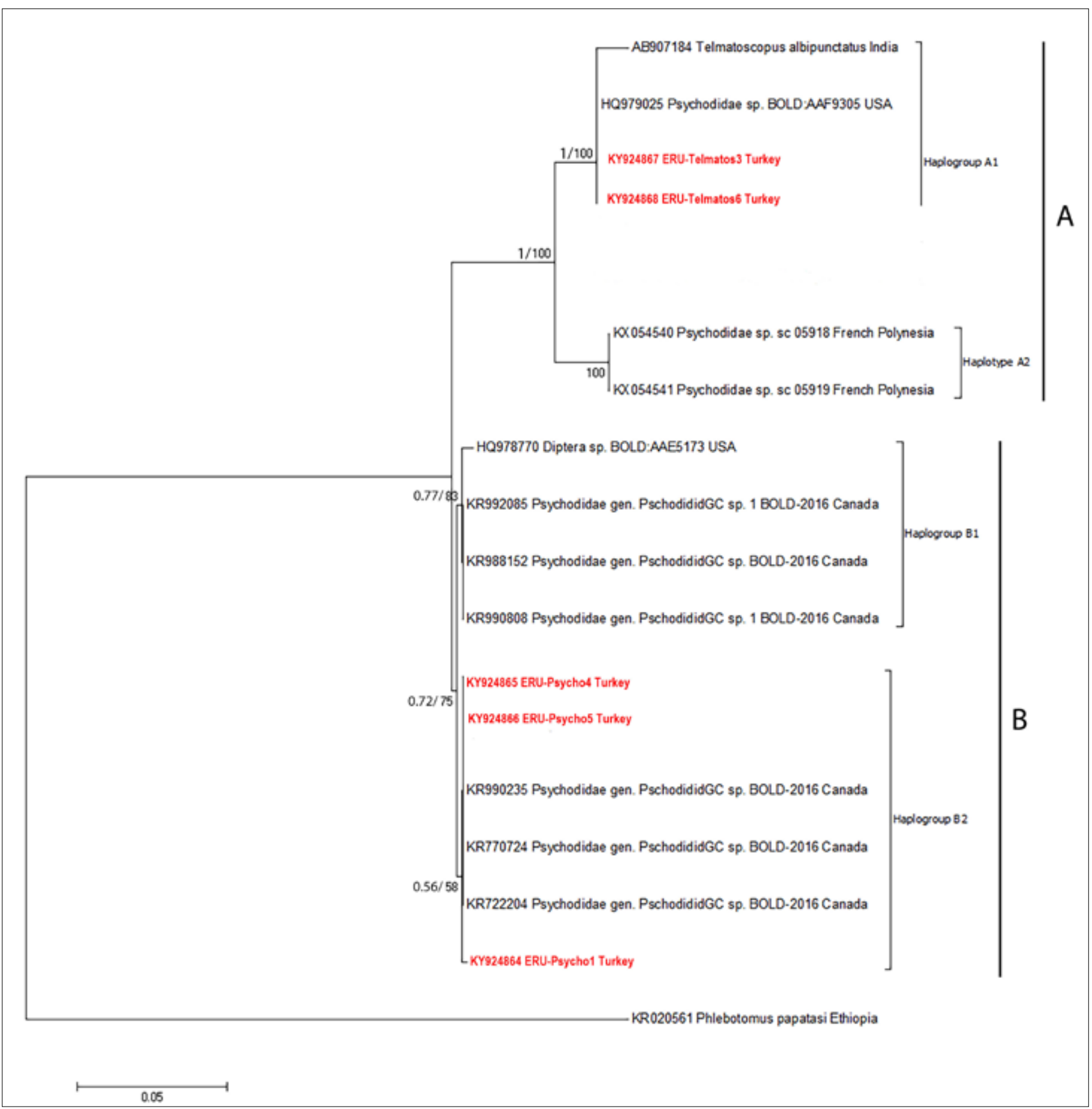

Figure 2. Phylogenetic relationships among the obtained moth flies and some other moth fly isolates based on DNA barcoding. The evolutionary history was inferred by the Bayesian method based on the GTR+G substitution model using the Geneious 9.1.3 software. We used the bootstrap analysis, which was conducted with 1000 replicates by the MEGA6 software to estimate the node reliability of the trees. Sequences were given as the GenBank accession number and country. Sequences in red type were obtained in this study. The haplogroups are indicated with A and B. The Phlebotomus papatasi (GenBank Accession No. KR020561) mt-COI sequence was used as an outgroup

\section{DISCUSSION}

Psychodinae are a subfamily of the Psychodidae family and known as moth, drain, or filter flies. Approximately 2000 species within this subfamily have been described in about 100 genera distributed all over the world (31). Adult moth fly species have been reported in toilets, kitchens, bathrooms, and sewers in different geographical regions of the world (10-12, 32). Adult C. albipunctata was observed in kitchens, toilets, and bathrooms, and also in a compost heap in Belgium (5). Obona and Jezek were collecting adult C. albipunctata in and on many buildings 
in different districts of Slovakia (14). Similarly, in this study, adult moth flies were collected from the walls of toilets, bathrooms, and basements of buildings in Kayseri, Turkey.

Correct species identification of psychodid flies is important for pest control practices (13). The traditional morphological identification of fly species used the morphological features between species. Most authors suggested that the morphological characters of drain flies are most closely related to other insect species $(6,14)$. However, the identification of adult psychodid species by using morphological characters is difficult and can be misidentified (33). Whereas phylogenetic relationships and classification within the Psychodidae family is only known for the subfamily Phlebotominae, species-rich Pscyhodinae subfamily relationships with other species and within the family remains poorly understood (18). At present, studies on the clasification of the Pscyhodinae subfamily are generally based on the morphology of all life stages (egg, larvae, and adult) and fossil species (3437). Hennig (34) and Azar et al. (35) suggested a clade Trichomyiinae+Sycoracinae+Horaiellinae to be the sister group of the Psychodinae based on the morphology of mainly fossil species.

With the development of molecular techniques, the PCR technique, which mainly targets the nuclear and mitochondrial genes, has been most commonly used in molecular characterization and phylogenetic analyses of insect species in recent years $(16,17)$. The cytochrome b (cytb), mt-COI and mt-COII, NADH dehydrogenase subunit 1, and $28 \mathrm{~S}$ and $16 \mathrm{~S}$ ribosomal RNA gene regions were used to determine relationships within the subfamily Psychodinae in different region of the world (18). The molecular analyses of mitochondrial DNA have ensured diagnostic markers for the identification of species in many different insect groups. The mitochondrial-encoded genes, COI and COIl, are among the more robust and reliable molecular markers for identification and phylogenetic analyses in most insect species because this gene region has highly conserved sequences and variable regions in vertebrates and insects $(15-17,38)$.

There have been no molecular-based studies conducted on moth flies in Turkey up to date, to the best of our knowledge. In this study, we describe the genotype characterization of moth flies by the DNA barcoding method based on mt-COI. We further determined phylogenetic relationships within the moth fly's specimens. Our results demonstrate that ERU-Telmatos 3 and ERU-Telmatos6 isolates are grouped with T. albipunctatus isolates in India and Psychodidae sp. isolate in the United States. These species are located under the A1 haplogroup with a high bootstrap support (100\%) and posterior probability (1.00) (Figure 2). According to the sequence BLAST analyses, the mean genetic distance between the $A 1$ haplogroup and the $A 2$ haplotype was $3.5 \pm 0.8 \%$.

Phylogenetic analyses revealed that the ERU-Psycho4 and ERU-Psycho5 isolates showed a 100\% identity among the Psychodidae sp. isolates in Canada. The ERU-Psycho1 isolate within the B2 haplogroup was characterized as a new haplotype in this study. The genetic difference between the B2 haplogroup isolates and the ERU-Psycho1 isolates was calculated as $0.2 \pm 0.2 \%$. The mean genetic distance between the Diptera sp. isolate from the United States and Psychodidae sp. isolate from Canada with- in the B1 haplogroup and ERU-Psycho1 was $0.5 \pm 0.2 \%$. However, high genetic diversity (5.6 $\pm 1.0 \%)$ was found between the groups $A$ and $B$. There are a limited number of studies on the phylogenetic relationship of the Psychodinae subfamily based on the mt-COI gene region in all world $(18,32)$. Espindola et al. (18) examined phylogenetic relationships among 52 Palearctic taxa of Psychodinae based on the mitochondrial DNA sequence. They report monophyly of the subfamily Psychodinae, and they found Psychodini samples in Clade II and also Psychoda comprised in several subclades of Clade II. Mokhtar et al. (32) found larvae in a 41-year-old female patient's feces in Malaysia. They were examinining the larval specimen under a stereomicroscope and identified as a Psychodid larva. Then the COI gene region by DNA barcoding of larvae was amplified using primer pairs, and the DNA barcode from the specimen suggested that the specimen was the larval stage of $C$. albipunctatus.

\section{CONCLUSION}

Our study provided the first set of data on the molecular characterization and phylogeny of moth flies based on the DNA barcoding in Turkey. We provide an understanding of phylogenetic reconstruction of these species to determine the vectorial potentiality and epidemiology of moth flies in Turkey, and thus the results of our analyses may be fruitful in future research. Furthermore, this study may be helpful to determine proper pest management practices against the moth flies.

Ethics Committee Approval: Due to the material composed from insect specimens Ethics Committee Approval was not needed for this study.

Informed Consent: Not required in this study.

Peer-review: Externally peer-reviewed.

Author Contributions: Concept - Z.Ö., A.I., A.Y.; Design - Z.Ö., A.I., A.Y., Ö.D., A.Ç.; Supervision - Z.Ö., A.I., A.Y.; Funding - Z.Ö., A.I., A.Y.; Materials - Z.Ö., A.I., A.Y.; Data Collection and/or Processing - Z.Ö., A.I., A.Y., Ö.D., A.Ç.; Analysis and/or Interpretation - Z.Ö., A.I., A.Y.; Literature Review - Z.Ö., A.I., A.Y., Ö.D., A.Ç.; Writing - Z.Ö., A.I., A.Y.; Critical Review - Z.Ö., A.I., A.Y.

Conflict of Interest: Authors have no conflicts of interest to declare.

Financial Disclosure: The authors declared that this study has received no financial support.

Etik Komite Onayı: Çalışma materyalini insektler oluşturduğundan etik komite onayı alınmamıştır.

Hasta Onamı: Bu çalışma için hasta onamına gerek yoktur.

Peer-review: Externally peer-reviewed.

Yazar Katkıları: Fikir - Z.Ö., A.I., A.Y.; Tasarım - Z.Ö., A.I., A.Y., Ö.D., A.Ç.; Denetleme - Z.Ö., A.I., A.Y.; Kaynaklar - Z.Ö., A.I., A.Y.; Malzemeler - Z.Ö., A.I., A.Y.; Veri toplanmasıve/veya işlemesi - Z.Ö., A.I., A.Y., Ö.D., A.Ç.; Analiz ve/veya yorum - Z.Ö., A.I., A.Y.; Literatür taraması - Z.Ö., A.I., A.Y., Ö.D., A.Ç.; Yazıyı yazan - Z.Ö., A.I.., A.Y.; Eleştirel Inceleme - Z.Ö., A.I., A.Y.

Çıkar Çatışması: Yazarlar çıkar çatışması bildirmemişlerdir.

Finansal Destek: Yazarlar bu çalışma için finansal destek almadıklarını beyan etmişlerdir. 


\section{REFERENCES}

1. Pape T, Blagoderov V, Mostovski MB. Order Diptera Linnaeus, 1758. (Ed) Animal biodiversity: An outline of higher-level classification and survey of taxonomic richness (ed. by Zhang Z-Q). Zootaxa 2011; 3148: 222-9.

2. Curler GR, Moulton JK. Phylogeny of psychodid subfamilies (Diptera: Psychodidae) inferred from nuclear DNA sequences with a review of morphological evidence for relationships. Syst Entomol 2012; 37: 603-16. [CrossRef]

3. Rutledge LC, Gupta RK. Moth flies and sand flies. Medical and Veterinary Entomology, (ed. by Mullen, R and L.A Durden), 2009; pp. 153-168, London.

4. Tu W, Chen H, Chen K, Tang LC, Lai SC. Intestinal myiasis caused by larvae of Telmatoscopus albipunctata in a Taiwanese man. J Clin Gastroenterol 2007; 41: 400. [CrossRef]

5. Boumans L, Zimmer JY, Verheggen F. First records of the 'bathroom moth midge' Clogmia albipunctata, a conspicuous element of the Belgian fauna that went unnoticed (Diptera: Psychodidae). Phegea 2009; 37: 153-60.

6. Kvifte GM. Biodiversity Studies in Afrotropical Moth Flies (Diptera: Psychodidae). Master thesis. Biology-Biodiversity, Evolution and Ecologyn University of Bergen 2011.

7. Verheggen F, Mignon J, Louis J, Haubruge E, Vanderpas J. Moth flies (Diptera: Psychodidae) in hospitals: a guide to their identification and methods for their control. Acta Clin Belg 2008; 64: 251-5. [CrossRef]

8. Higuchi K, Saitoh H, Mizuki E, Hwang SH, Ohba M. A novel isolate of Bacillus thuringiensis serovar leesis that specifically exhibits larvicidal activity against the moth-fly, Telmatoscopus albipunctatus. Syst Appl Microbiol 1998; 21: 144-50. [CrossRef]

9. Merritt RW, Courtney GW, Keiper JB. Chapter 76-Diptera: (flies, mosquitoes, midges, gnats). In: Cardé, V.H.R.T. (ed.) Encyclopedia of insects. Academic Press 2009, San Diego CA, USA, pp. 284-97. [CrossRef]

10. Rocha T, de Oliveira David JA, Caetano FH. Ultramorphological features of the egg of Telmatoscopus albipunctatus (Williston) (Diptera, Psychodidae). Rev Bras Entomol 2011; 55: 179-82. [CrossRef]

11. Robinson WH. Urban insects and arachnids. A handbook of Urban Entomology, Cambridge University Press 2005; pp.181-2. [CrossRef]

12. El-Badry AA, Salem HK, El-Aziz Edmardash YA. Human urinary myiasis due to larvae of Clogmia (Telmatoscopus) albipunctata Williston (Diptera: Psychodidae) first report in Egypt. J Vector Borne Dis 2014; 51: 247-9.

13. Jiménez-Guri E, Wotton KR, Gavilán B, Jaeger J. A staging scheme for the development of the moth midge Clogmia albipunctata. PLoS One 2014; 7: 9. [CrossRef]

14. Oboňa J, Ježek J. Range Expansion of the invasive moth midge Clogmia albipunctata (Williston, 1893) in Slovakia (Diptera: Psychodidae). Fol Faun Slovaca 2012; 17: 387-91.

15. Otranto D, Stevens JR. Molecular approaches to the study of myiasis causing larvae. Int J Parasitol 2002; 32: 1345-60. [CrossRef]

16. Lin $\mathrm{CP}$, Danforth $\mathrm{BN}$. How do insect nuclear and mitochondrial gene substitution patterns differ? Insights from Bayesian analyses of combined datasets. Mol Phylogenet Evol 2004; 30: 686-702. [CrossRef]

17. Barr NB, Islam MS, De Meyer M, McPheron BA. Molecular identification of Ceratitis capitata (Diptera: Tephritidae) using DNA sequences of the COI barcode region. Ann Entomol Soc Am 2012; 105: 33950. [CrossRef]

18. Espindola A, Buerki S, Jacquier A, Ježek J, Alvarez N. Phylogenetic relationships in the subfamily Psychodinae (Diptera, Psychodidae). Zool Scr 2012; 41: 5. [CrossRef]
19. Faulde M, Spiesberger M. Role of the moth fly Clogmia albipunctata (Diptera: Psychodinae) as a mechanical vector of bacterial pathogens in German hospitals. J Hosp Infect 2013; 83: 51-60. [CrossRef]

20. Folmer O, Black M, Hoeh W, Lutz R, Vrijenhoek R. DNA primers for amplification of mitochondrial cytochrome c oxidase subunit I from diverse metazoan invertebrates. Mol Mar Biol Biotechnol 1994; 3: 294-9.

21. Kearse $M$, Moir R, Wilson A, Stones-Havas $S$, Cheung $M$, Sturrock $S$, et al. Geneious Basic: an integrated and extendable desktop software platform for the organization and analysis of sequence data. Bioinformatics 2012; 28: 1647-9. [CrossRef]

22. Librado P, Rozas J. DnaSP v5: a software for comprehensive analysis of DNA polymorphism data. Bioinformatics 2009; 25: 1451-2. [CrossRef]

23. Tamura K, Stecher G, Peterson D, Filipski A, Kumar S. MEGA6: Molecular evolutionary genetics analysis version 6.0. Mol Biol Evol 2013; 30: 2725-9. [CrossRef]

24. Kimura M. A simple method of estimating evolutionary rate of base substitutions through comparative studies of nucleotide sequences. J Mol Evol 1980; 16: 111-20. [CrossRef]

25. Nei M, Kumar S. Molecular evolution and phylogenetics. Oxford University Press 2000; pp. 348.

26. Rodríguez F, Oliver JL, Marín A, Medina JR. The general stochastic model of nucleotide substitution. J Theor Biol 1990; 142: 485-501. [CrossRef]

27. Posada D. jModelTest: phylogenetic model averaging. Mol Biol Evol 2008; 25: 1253-6. [CrossRef]

28. Huelsenbeck JP, Ronquist F. MRBAYES: Bayesian inference of phylogenetic trees. Bioinformatics 2001; 17: 754-5. [CrossRef]

29. Guindon S, Gascuel O. A simple, fast, and accurate algorithm to estimate large phylogenies by maximum likelihood. Syst Biol 2003; 52: 696-704. [CrossRef]

30. Crozier RH, Crozier YC. The mitochondrial genome of the honeybee Apis mellifera: complete sequence and genome organization. Genetics 1993; 133: 97-117.

31. Wagner R, B'artak M, Borkent A, Courtney G, Goddeeris B, Haenni JP. Global diversity of dipteran families (Insecta Diptera) in freshwater (excluding Simuliidae, Culicidae, Chironomidae, Tipulidae and Tabanidae). Hydrobiologia 2008; 595: 489-519. [CrossRef]

32. Mokhtar AS, Braima KA, Peng Chin H, Jeffery J, Mohd Zain SN, Rohela $\mathrm{M}$, et al. Intestinal myiasis in a Malaysian patient caused by larvae of Clogmia albipunctatus (Diptera: Psychodidae). J Med Entomol 2016; 53: 957-60. [CrossRef]

33. Quate LW. The Psychodidae of Batu Caves, Malaya. Pacific Insects 1962; 4: 219-34.

34. Hennig W. Insektenfossilien aus der unteren Kreide IV. Psychodidae (Phlebotominae), mit einer kritischen Ubersicht uber das phylogenetische System der Familie und die bisher beschriebenen Fossilien (Diptera). Stutt Beitr Naturkd 1972; 241: 1-69.

35. Azar D, Nel A, Solignac M, Paicheler JC, Bouchet FO. New genera and species of phlebotomid and psychodid flies from the Lower Cretaceous amber of Lebanon (Insecta: Diptera: Phlebotomidae, Psychodidae). Palaeontology 1999; 42: 1101-136. [CrossRef]

36. Wood DM, Borkent A. Phylogeny and classification of the nematocera. In: McAlpine JF, Wood DM, eds. Manual of nearctic Diptera, vol. 3. Ottawa: Research Branch Agriculture Canada (Biyosystematic Research Center) 1989; 1333-70.

37. Stebner F, Solórzano Kraemer MM, Ibáñez-Bernal S, Wagner R. Moth flies and sand flies (Diptera: Psychodidae) in Cretaceous Burmese amber. Peer J 2015; 17: 3.

38. Lunt DH, Zhang DX, Szymura JM, Hewitt GM. The insect cytochrome oxidase 1 gene: evolutionary patterns and con-served primers for phylogenetic studies. Insect Mol Biol 1996; 5: 153-65. [CrossRef] 